\title{
Enhancing Tools for Sustainable Health Communication within Covid-19

\author{
Jiří Maštálka
}

\author{
Konstantinovy Lazne healthcare center, Western Bohemia, Czech Republic \\ mastalka_jiri@gmail.com
}

\begin{abstract}
The paper provides short commentary on key features of public health communication during the current pandemic. The paper contains empirical analysis of field data from international, regional, and local national sources related to the industry, institutions, research in the field of study. The thematic content analysis through the computer-based coding served as the background investigation method. The study provides preliminary data on the key topics within official communication on health care issues during COVID-19, explores challenges to communication on health issues during COVID-19, identifies possible tools for sustainable health communication in the current COVID-19 pandemic, and outlines tentative recommendations to foster sustainable communication on health issues during the pandemic.
\end{abstract}

Keywords: health communication, COVID-19, language planning

\section{For citation:}

Maštálka J. (2021). Enhancing Tools for Sustainable Health Communication within COVID19 // Human Language, Rights, and Security. Vol. 1. № 1. P. 19-25. DOI: 10.22363/2713-06142021-1-1-19-25

\section{INTRODUCTION}

The third Millennium witnesses unprecedented flow of healthcare emergencies, including flues, AIDS, Zika, MERS, and COVID-19. Therefore, communication on healthcare issues has become one of critical instruments for the contemporary society to cope with such global challenges and keep safe. The present paper aims to provide brief commentary on those topics which shape the health communication during COVID-19.

The hypothesis states that along with official communication on COVID-19 at international, regional, and national levels the current pandemic has brought to light challenges and solutions which stem from the world globalization and digitalization.

The paper explores the following research questions: 
- What are key topics within official communication on health care issues during COVID-19?

- What are challenges to communication on health issues during COVID 19?

- What are possible tools for sustainable health communication in the current COVID-19 pandemic?

\section{Research Design}

The research design incorporated diverse field data for empirical analysis. The sample included publications of the international, regional and national authorities and agencies, and the academic papers, as well. Totally over 478 sources were subject to study.

The Google search engine with the keyword COVID-19 health communication/information was used for selection of institutional data. The Google Scholar database was also used for selection of academic papers for brief review of relevant literature on the topic under study. The custom rage was limited to the year of 2020.

The study used thematic content analysis through the computer -based coding by QDA Minor Lite application.

\section{Preliminary Results and Discussion}

\subsection{Key topics within official communication on health care issues during COVID-19}

Major international stakeholders, including the United Nations (UNO) and the World Health Organization (WHO) consider effective and coordinated communications as a critical instrument to foster the global community health, this vision becomes even stronger during COVID-19 (Communicating for health, n/d, Coronavirus global health emergency, 2020).

Regional institutions, for instance, the European Union policies (ECDC activities on health communication, 2020), Pan American Healthcare Organization actions (COVID-19: Communication Materials, 2020) promote the same approach. The mentioned stakeholders share background information about the virus and preventive measures for the population, data for professionals and the public regarding preventive measures, vaccination development and campaign.

At national level, countries also try to enhance consistent health communication, tailor information for general population and professionals, update treatment protocols for disease different phases, specify health service provision for particular audiences (Coronavirus COVID-19, 2020).

Specific emphasis is laid on support for doctor's wellbeing, see for instance, recommendations of British Medical Association (COVID-19: your wellbeing, 2020), and the recommendations provided by the Czech republic authorities (COVID-19 - Key issues and measures in the Czech Republic, 2020). 
In line with the global community vision, Academia considers communication on health issues during COVID-19 within crisis and emergency risk communication framework (Abrams \& Greenhawt ,2020). Scholars underline the critical value of information transparency and trust during the COVID-19 pandemic (Spalluto et al., 2020), specify the need to carefully consider genres of leadership and authorities' messages (Koh et al., 2020), highlight the need for doctors to master specific communicative skills (Rubinelli et al. 2020), explore ethical aspect of health communication during pandemics (Iserson, 2020), consider and evaluate the potential of healthcare professionals' empathy in the course of their communication with patients (Rossi et al., 2021), psychological support for doctors (Walton et al. 2020). Scholars also explore the role of the mass media in raising public awareness of risk and shaping relevant knowledge (Karasneh, et al. 2020).

\subsection{Challenges to communication on health issues during COVID-19}

During the COVID 19 the world has faced unprecedent spread of misinformation through digital formats. Efforts to fight it have been undertaken at international, regional and national levels. The UN addressed a relevant guidance to its agencies, member states, media, civil society and tech companies (United Nations Guidance Note... 2020). The European Commission shaped the Action Plan to fight illegal or false contents, to enhance digital tools potential for authoritative information, to foster fact checking and research, to support the media and civil society as essential actors of reliable, fact-checked information delivery (Tackling COVID-19 disinformation, 2020). National agencies implemented legal measures, as well. Operative activities against social media which spread misinformation were conducted in the UK (Miller, 2020). Countries across the world were ready to criminalize the misinformation activities (Budryk 2020).

The current pandemic revealed the need for multilingual solutions for communication on health issues during the pandemic within modern communities which integrate nationals migrating from different countries, on the one hand, and indigenous people, on the other. The matter has been subject to activities of international and regional organizations, see the UNO, WHO, EU sites mentioned in previous sections. At national level, countries also tried to develop multilingual platforms on COVID-19 prevention and treatment, see for instance, multilingual resources of the USA Centers for Disease Control and Prevention (Communication Resources, 2020).

However, these actions were not coordinated as policy actions. Biased and sensational language in the media increased tensions in community, as well. Analysts point out that media language tended to used criminalizing or dehumanizing terminology with ethnicity affiliation. For instance, some mass media affiliated with different countries and institutions across countries used sensational headlines with reference to China (Coronavirus - Made in China, 2020). Analysts draw attention to careful use of language with regard to explicit mentions or implicit references to vulnerable audiences 
(Obosi, 2020). Such an approach was strongly criticized by the key international stakeholders (McCartney et al., 2021).

The countries of the Visegrad group (Urbanovics et al., 2021) have also paid a specific attention to the socio-political impacts of the COVID-19 pandemic $t$ with respect to the V4 countries, including information provision issues.

\subsection{Possible tools for health communication development in the current COVID-19 pandemic}

The current pandemic has revealed the Artificial Intelligence potential within health emergencies.

The WHO has launched WhatsApp chatbot to inform the public about the new coronavirus infection. The initiative was also supported by Singapore, Israel, South Africa, Indonesia (Bucher, 2020). Moreover, WHO regional office for Europe launched a similar regional AI-based service. It provides countermeasures to misinformation and myths, delivers accurate information about COVID-19 in several languages (HealthBuddy, 2020).

Regarding the Czech Republic, recent comparative studies reveal how the Czech and Austrian COVID-19 mobile phone apps in the battle against the virus (Stehlíková, 2021).

Bearing in mind the data of previous sections, it seems logical and reasonable that both industry stakeholders (Tagliacozzo et al., 2021), institutional agencies (Lau et al., 2021), and Academia (Xiao et al., 2021) set forth the need for coordinated language policies and communication planning for health emergencies.

Respective activities imply guidelines for language use, multilingual information provision, the mentioned documents being coordinated at international, regional, and national levels ( Dreisbach \& Mendoza-Dreisbach, 2021).

Moreover, both Industry and Academia argue for the urgent importance to create interagency and international interactive tools and platforms to provide real-time alerts of rumors about coronavirus, the instruments would enable health officials and relevant stakeholders to respond rapidly with a proactive and engaging narrative to mitigate misinformation (Depoux et al., 2020).Such actions can foster ecosocial approaches to solving social problems (Jusko, 2020).

\section{Concluding Remarks}

The data reveals that the world globalization and digitalization produce an impact on the phenomenon of public health communication during the COVID-19. Along with official communication on health care issues some challenges emerge due to cross-cultural bias, national identity matters, specific language use in the mass communication, increasing gadget applications spread. The international and national 
actors who engaged in public health communication should go beyond the healthcare topics themselves, take into account emerging challenges and think of communication policies which would respond to the global public good and meet the national specifics, contribute to community resilience, and work for society sustainable development.

\section{REFERENCES}

Abrams, E. M. \& Greenhawt, M. (2020). Risk communication during COVID-19. The Journal of Allergy and Clinical Immunology: In Practice, 8 (6), 1791-1794. https://doi.org/10.1016/ j.jaip.2020.04.012

Bucher, B. (2020). Covid-19: World Health Organization (WHO) consults via WhatsApp chatbot. Messengerpeople. https://www.messengerpeople.com/covid-19-world-health-organization-viawhatsapp-chatbot/

Budryk, Z. (2020). India, Thailand, Germany warn of punishment for coronavirus misinformation on April Fools' Day. The Hill. https://thehill.com/policy/international/india/490403-indiathailand-germanywarn-of-punishment-for-coronavirus

Communicating for health (n/d). World Health Organization. https://www.who.int/about/com munications (accessed June 1, 2021).

Communication Resources (2020). Centres for Disease Control and Prevention. https:// www.cdc.gov/coronavirus/2019-ncov/communication/index.html (accessed June 1, 2021). virus

Coronavirus global health emergency (2020). United Nations. https:// www.un.org/en/corona

Coronavirus (COVID-19) (2020). UK Government. https://www.gov.uk/coronavirus

COVID-19: Communication Materials (2020). Pan American Healthcare Organization. https:/www.paho.org/en/covid-19-communication-materials

Coronavirus disease COVID-19: Coronavirus-related recommendations for psychologists. https://www.mvcr.cz/mvcren/article/coronavirus-disease-covid-19-coronavirus-related-recommendations-for-psychologists.aspx

COVID-19 - Key issues and measures in the Czech Republic. https://www.dentons.com/en/ insights/articles/2020/march/25/covid-19---key-issues-and-measures-in-the-czech-republic

Coronavirus - Made in China (2020). Der Spiegel, 6. https://www.spiegel.de/spiegel/print/ index-2020-6.html

COVID-19: your wellbeing (2020). British Medical Association. https://www.bma.org.uk/ advice-and-support/covid-19/your-health/covid-19-your-wellbeing

Depoux, A., Martin, S., Karafillakis, E., Preet, R., Wilder-Smith, A. \& Larson, H. (2020). The pandemic of social media panic travels faster than the COVID-19 outbreak. Journal of Travel Medicine, 27 (3), taaa031, https://doi.org/10.1093/jtm/taaa031

Dreisbach, J.L. \& Mendoza-Dreisbach, S. (2021). The integration of emergency language services in COVID-19 response: a call for the linguistic turn in public health. Journal of Public Health, 43(2), e248-e249.

ECDC activities on health communication (2020). European Union Centre for Disease Prevention and Control. https://www.ecdc.europa.eu/en/about-us/what-wedo/health-communicationactivities

HealthBuddy (2020). World health Organization. https://healthbuddy.info/index\#webchat

Iserson, K.V. (2020). Healthcare ethics during a pandemic. Western Journal of Emergency Medicine, 21(3), 477-483. https://doi.org/10.5811/westjem.2020.4.47549 
Karasneh, R., Al-Azzam, S., Muflih, S., Soudah, O., Hawamdeh, S. \& Khader, Y. (2020). Media's effect on shaping knowledge, awareness risk perceptions and communication practices of pandemic COVID-19 among pharmacists. Research in Social and Administrative Pharmacy. https://doi.org/10.1016/j.sapharm.2020.04.027

Jusko, P. (2020). Ecosocial Approaches in Solving Social Problems on the Example of the First Wave of the SARS-CoV-2 Pandemic. PhD Disertation. Wyższa Szkoła Zarządzania i Administracji w Opolu. ISBN 978-83-66567-17-7.

Koh, P.K.K., Chan, L.L. \& Tan, E.K. (2020). Messaging Fatigue and Desensitisation to Information During Pandemic. Archives of Medical Research. [Epub ahead of print]. 10.1016/j.arcmed.2020.06.014

McCartney G., Leyland A., Walsh D. \& Ruth D. (2021). Scaling COVID-19 against inequalities: should the policy response consistently match the mortality challenge? J Epidemiol Community Health, 75(4), 315-320. https://dx.doi.org/10.1136/jech-2020-214373

Miller C. (2020). Coronavirus: Far-right spreads Covid-19 'infodemic' on Facebook. BBC news. https://www.bbc.com/news/technology-52490430

Obosi S. (2020, April 14) Opinion: We need to change the language around COVID19. Devex. https://www.devex.com/news/opinion-we-need-to-change-thelanguage-around-covid-19-96977

Rossi, A.A., Marconi, M., Taccini, F., Verusio, C. \& Mannarini, S. (2021). From Fear to Hopelessness: The Buffering Effect of Patient-Centered Communication in a Sample of Oncological Patients during COVID-19. Behavioral Sciences, 11(6), 87. https://doi.org/10.3390/bs11060087

Rubinelli, S., Myers, K., Rosenbaum, M. \& Davis, D. (2020). Implications of the current COVID-19 pandemic for communication in healthcare. Patient Education and Counseling, 103(6), 1067-1069. https://doi.org/10.1016/j.pec.2020.04.021

San Lau, L.I.N.G., Hooper, K. \& Zard, M. (2021). From Unilateral Response to Coordinated Action. Migration Policy Institute. https:/www.migrationpolicy.org/sites/default/files/publica tions/mpi-ssa-mobility-public-health-2021_final.pdf

Spalluto, L.B., Planz, V.B., Stokes, L.S., Pierce, R., Aronoff, D.M., McPheeters, M.L., \& Omary, R.A. (2020). Transparency and trust during the coronavirus disease 2019 (COVID-19) pandemic. Journal of the American College of Radiology, 17(7), 909-912.

Stehlíková, J. (2021). The corona crisis, data protection and tracking apps in the EU: the Czech and Austrian COVID-19 mobile phone apps in the battle against the virus. Mezinárodní vztahy, 56(1), 35-67. https://doi.org/10.32422/mv-cjir.1764

Tackling COVID-19 disinformation - Getting the facts right (2020, June 10). European Commission. https://eur-lex.europa.eu/legalcontent/EN/TXT/PDF/?uri=CELEX:52020JC0008\& from $=\mathrm{EN}$

Tagliacozzo, S., Albrecht, F. \& Ganapati, N.E. (2021). International Perspectives on COVID19 Communication Ecologies: Public Health Agencies' Online Communication in Italy, Sweden, and the United States. American Behavioral Scientist, 65(7), 934-955. https://doi.org/10.1177/ 0002764221992832

Urbanovics, A., Sasvári, P. \& Teleki, B. (2021). Evaluation of the COVID-19 regulations in the Visegrad group. Transforming Government: People, Process and Policy. Vol. ahead-of-print No. ahead-of-print. https://doi.org/10.1108/TG-08-2020-0228

United Nations Guidance Note on Addressing and Countering COVID-19 related Hate Speech (2020, May 11). United Nations. https://www.un.org/en/genocideprevention/documents/Guidance \%20on\%20COVID-19\%20related\%20Hate\%20Speech.pdf

Walton, M., Murray, E. \& Christian, M.D. (2020). Mental health care for medical staff and affiliated healthcare workers during the COVID-19 pandemic. European Heart Journal: Acute Cardiovascular Care, 9(3). https://doi.org/10.1177/2048872620922795 
Xiao, Y., Peng, Q. \& Xu, W. (2021). Evolutionary Game Analysis of Cross-Regional Coordinated Governance of Major Public Health Emergencies: The Example of the Spread of the COVID19 Outbreak. Mathematical Problems in Engineering, Article ID 9992163 https://doi.org/10.1155/ $\underline{2021 / 9992163}$

\section{AUTHOR'S BIO:}

Jiří Maštálka - MUDr. Czech member of Czech Parliament (1996-2019), politician and doctor, member of ČLK; Society of Cardiology J.E.P. Currently holds a senior position in the Konstantinovy Lazne healthcare center (Western Bohemia, the Czech Republic)

ORCID: 0000-0002-3191-7343 